\title{
Potential of indigenous strains of entomopathogenic nematodes under laboratory and Protected environment conditions for the control of Tuta absoluta (Meyrick) (Lepidoptera: Gelechiidae) of North-Western Himalayas
}

Indra Kumar Kasi ( $\nabla$ entomologist2018@gmail.com )

Department of Entomology, Dr. Yashwant Singh Parmar University of Horticulture and Forestry, -173230, Himachal Pradesh, India.

Mohinder Singh

Department of Entomology, Dr. Yashwant Singh Parmar University of Horticulture and Forestry, -173230, Himachal Pradesh, India.

Kanchhi Maya Waiba

Department of Horticulture, Institute of Agricultural Sciences, Banaras Hindu University Varanasi - 221005, India.

P L Sharma

Department of Entomology, Dr. Yashwant Singh Parmar University of Horticulture and Forestry, -173230, Himachal Pradesh, India.

\section{Research Article}

Keywords: Entomopathogenic, Mortality, Tomato, Tuta absoluta, Greenhouse

Posted Date: January 12th, 2022

DOI: https://doi.org/10.21203/rs.3.rs-1205792/v1

License: () (1) This work is licensed under a Creative Commons Attribution 4.0 International License. Read Full License 


\section{Abstract \\ Background}

Entomopathogenic nematodes (EPNs) are a type of biological control agent that has been extensively studied. Under field and laboratory settings, the efficiency of two EPNs species, Heterorhabditis indica and Steinernema feltiae, isolated locally from soils of Rajghar, Himachal Pradesh, India, against an important invasive pest, Tuta absoluta (Meyrick) (Lepidoptera: Gelechiidae), was assessed.

\section{Results}

Steinernema feltiae (isolate- HR-1) and Heterorhabditis indica (isolate- HA-2) species dose $\left(10,20,40,80,160 \mathrm{IJs} / \mathrm{cm}^{2}\right)$ are used in the lab bioassay. The third instar (percentage) ranges from 24.15 to 90.00 percent. HR1 and HA2 isolates demonstrated significant larvicidal activity with LC $50, L_{75}$, and LC ${ }_{90}$ of all instars and pupa show high mortality from 31.53 to 90.00 percent and 72-hours exposure duration. The strain slows larval development in 48 to 72 hours of exposure period, with $\mathrm{LC}_{50}$ values ranging from 05.42 to $19.29, \mathrm{LC}_{75}$ values ranging from 20.29 to 83.12 , and $\mathrm{LC}_{90}$ values ranging from 26.03 to 78.89 . Greenhouse test seam isolates are foliar sprayed three times at a 14-day interval, with total findings revealing a 7.36 ore count range before spraying. The total treatment outcomes range from 1.64 to 1.74 for isolate HA-2, and 1.88 and 2.03 for HR-1. 4.15 percent was recorded in the control plot.

\section{Conclusion}

Invasive species pose a significant threat, as evidenced by this research. Traditional EPNs ( . feltiae HR-1, H. indica HA-2) have been used as an active biocontrol agent in laboratory and greenhouse settings, as well as the pathogen that infects $T$. absoluta.

\section{Background}

Tuta absoluta (Meyrick) (Lepidoptera: Gelechiidae), an invasive tomato leaf miner, is endemic to South America. The pest was initially spotted outside of its native habitat in Spain in 2006 (Urbaneja et al., 2008), and it has since spread to 80 nations, including India (CABI, 2018). In the absence of regulatory measures, the insect feeds on leaves, fruits, shoots, and apical shoots of tomatoes, which can cause 100 percent damage to plants (Urbaneja et al., 2012; Balal et al., 2016). The appearance of this bug in India was first traced to tomato cultivation in Pune and Bangalore in 2014 (Sridhar et al., $2014 ;$ Shashank et al., 2015), and it has since spread to practically every section of the country (Sridhar et al., 2014; Kalleshwaraswamy et al., 2015; Kumari et al., 2015; Shashank et al., 2015; Balal et al., 2016; Sharma and Gavkare, 2017). Tomatoes of T. absoluta were first discovered in Himachal Pradesh in 2015 in Nauni, Solan (Sharma and Gavkare, 2017). On problem-solving has arisen as a big hazard to tomatoes in open spaces and poly-houses throughout the state. Previous findings indicate that $T$. absoluta swiftly developed a serious insect condition in recent locations without the usage of drugs (Bielza, 2010; Desneux et al., 2010). Tuta absoluta control, in particular, based on pesticides, was required, with insecticides being used up to 14 times during the growth season (Luna et al., 2012). Because the larvae reside inside mines and fruits, where pesticides are difficult to come by, this bug is difficult to manage chemically. Biotic energy is high, and the ability to improve pesticide resistance keeps pests at bay is a difficulty (Desneux et al., 2010; Ingegno et al., 2013; Roditakis et al., 2013; Roditakis et al., 2015).

Global warming is occurring, and climate change is likely to have a significant impact on human energy and insect species. Temperature is the most essential element directly impacting insect development, survival, distribution, and abundance among climatic variables (Zhang et al., 2008; Ju et al., 2011; Gavkare and Sharma, 2017). As a result, it's critical to comprehend the file's temperature effect on the census. T. absoluta sees a rise in the spread of insect illnesses as a possibility. The impact of heat on insects is often quantified in terms of developmental state (Sreedevi et al., 2013; Liu et al., 2015). The earth-bound insecticides Heterorhabditidae and Steinernematidae are entomopathogenic nematodes (EPNs) (Kaya and Gaugler 1993). These nematodes have developed to interact with viruses from the Photorhabdus and Heterorhabditis genera, which are carried in the intestines of infectious hairs (IJs) (Arthurs et al., 2004). Xenorhabdus is related to Steinernema spp. and is found in the intestines of IJs on a specific skin. Following insect directions, nematodes locate a location where they can be trapped (Lewis et al., 2006). Infect the culprit with an opening such as the mouth, skull, or edges, or by inserting a cuticle after IJs have discovered the culprit (especially in Heterorhabditis spp.). IJs breach their outer cuticle as soon as they enter the host (Sicard et al., 2004) and begin to absorb the hemolymph, causing the annotations to release (Steinernema spp.) or to repeat (Heterorhabditis spp). (Geteral et al., 2005). With septicemia or toxaemia, nematodes - bacteria destroy the host in 24 to 48 hours (Forst and Clarke, 2002).

More than 100 varieties of EPNs have been identified globally, with steinernematid accounting for around $80 \%$ of these. Only $13 \%$ of these types have been commercialised (Abbas et al., 2021). In the management of important biodiversity, EPNs are commonly used (Grewal et al., 2005). Several investigations have found that EPNs can be used to control T. absoluta. Entomopathogenic nematodes (EPNs) (Tadele and Emana, 2017), entomopathogenic nematodes (EPNs) (Van Damme et al., 2016), and pesticides (Nilahyane et al., 2012) have all been extensively employed, although there have been few reports of their utilisation in the field.

When compared to white grubes in Rwanda (Kajuga et al., 2018), the geographical classification of EPNs (Yan et al., 2016) is effective, which is why more research into their efficiency in combatting other significant economic pests, such as $T$. absolute, is needed. In Rwanda, laboratory bioassays are being carried out to assess the performance of three types of environmental regulating agents: local EPNs, the sale of competing local plant products $T$. absoluta, and the sale of competing local plant products $T$. absoluta. Some agents have demonstrated excellent efficiency in each of the above groups. Because the most efficient laboratory can only be translated to specific outdoor settings (Lacey et al., 2015). The goal of this research was to offer the foundational information 
needed to use indigenously isolated EPNs as biological control agents. The study looked at the pathogenicity of two nematode species, $S$. feltiae and $H$. bacteriophora, against Tuta absoluta in both laboratory and field settings.

\section{Methods}

\section{Lab bioassays}

Petri dishes are used for bio-assays $(9 \mathrm{~cm})$. Each unit had $20 \mathrm{~g}$ of sandy dirt in it (Table 1$)$. The moisture content of the soil was adjusted to $7 \%$ (w/ $/ \mathrm{w})$. In $1 \mathrm{cc}$ of distilled water, IJs are applied evenly to the soil surface at $0,5,10,20,40,80$, and $160 \mathrm{IJs} / \mathrm{cm}^{2}$. The final soil moisture content was $10 \%(\mathrm{w} / \mathrm{w})$. Containers are then kept at room temperature for 1 hour before being filled with all larvae under $10 \mathrm{~T}$. absoluta. Each abuse was replicated four times. Containers are kept in a growth chamber for 72 hours under controlled circumstances. The larvae were then extracted from the substrate using a minor incision and housed separately in regulated settings until an adult developed. Three days later, $25 \%$ of dead larvae were randomly selected and used under stereomicroscope image analysis software (Olympus Soft Imaging Solutions) to confirm nematode infection. Tests were performed twice.

\section{Greenhouse Tests}

\section{Study site and period}

The experimental farm is located at an elevation of $1260 \mathrm{~m}$ above mean sea level with $30^{\circ} 52^{\prime} \mathrm{N}$ latitude and $77^{\circ} 11^{\prime} \mathrm{E}$ longitude with East-West orientation of poly-house which represents the mid-hill zone of Himachal Pradesh, India. This is an ideal location for a poly-house with various features like single door, side, and top vent, drip irrigation, fogging facility, and internal shading with a $50 \%$ green agro UV stabilized shade net.

\section{Plant material and treatments}

The tomato germplasm commercial market, $F_{1}$ Hybrid (BSS-816) were evaluated under a naturally ventilated poly-house having a $200 \mathrm{~m}^{2}$ area. The experiment was conducted in a randomized block design (RBD) with four replications inside the modified naturally ventilated poly-house (25 $\mathrm{m} \times 10 \mathrm{~m}$ ). Ten plants of the hybrid were planted at a spacing of $70 \times 30 \mathrm{~cm}$ and trained on two stems in each replication.

\section{Table 1.}

Treatments used in the field experiment to control Tuta absoluta (M.)

\begin{tabular}{|lll|}
\hline Designation & Treatment description & Type of treatment \\
\hline Native strain & Steinernema feltiae & Entomopathogenic nematode \\
\hline $\mathrm{T}_{1}$ & $1,00,000 \mathrm{IJs} / \mathrm{m}^{2}$ & Entomopathogenic nematode \\
$\mathrm{T}_{2}$ & $2,00,000 \mathrm{IJs} / \mathrm{m}^{2}$ & Entomopathogenic nematode \\
\hline $\mathrm{T}_{3}$ & $4,00,000 \mathrm{IJs} / \mathrm{m}^{2}$ & Entomopathogenic nematode \\
\hline & Heterorhabditis indica & \\
\hline $\mathrm{T}_{4}$ & $1,00,000 \mathrm{IJs} / \mathrm{m}^{2}$ & Entomopathogenic nematode \\
\hline $\mathrm{T}_{5}$ & $2,00,000 \mathrm{IJs} / \mathrm{m}^{2}$ & Entomopathogenic nematode \\
\hline $\mathrm{T}_{6}$ & $4,00,000 \mathrm{IJs} / \mathrm{m}^{2}$ & Entomopathogenic nematode \\
\hline $\mathrm{T}_{7}$ & Water spray & Untreated (Control) \\
\hline
\end{tabular}

\section{Entomopathogenic nematodes}

The two EPNs employed in this investigation (Table 1) were $S$. feltiae and $H$. indica isolates that were used without culturing in the tests. The native isolate was obtained using Galleria mellonella (L.) larvae as nematode baiting traps from fruit orchard soil samples collected from $1682 \mathrm{~m}$ above mean sea level with 30o 53' 15 N latitude and 77o 16' 07 E longitude with the mid-hill zone of the western Himalayas Rajgarh, Sirmaur district, Himachal Pradesh, India. The isolates were cultivated on $\mathrm{G}$. mellonella last instar larvae at $211^{\circ} \mathrm{C}$ using the technique (Kaya and Gaugler 1993). Infectious juveniles (IJs) were collected from white traps maintained at $4{ }^{\circ} \mathrm{C}$ in distilled water for up to 14 days once they emerged during the first 10 days. Before being employed in the tests, the nematodes were acclimatized at room temperature for around 30 minutes.

\section{Trial set-up and maintenance}

The field in (ploy-house) was ploughed twice in 15 days and treated with $20 \mathrm{t}$ ha- 2 cow dung before planting the test. With three responses, the test was placed on RBD (full random block format). The test unit (building) was 3 meters long and 2 meters broad, with 24 plants separated by 0.5 meters and 0.5 meters. To prevent the treatments from wandering, portions were placed $1.5 \mathrm{~m}$ apart. The 30 -day seedlings are used for the implantation, and the locations are covered with dried grass. Other operations such as watering, weeding, trimming four branches, each plant, fertilizer, and fungal are done in the same way in all regions, in addition to the use of various pesticides used in the study techniques. Because of its abundance in the research area, T. absoluta has launched an environmental attack (Sohrabi et al., 2017). 


\section{Application of treatments}

Treatments began one week after transplantation and continued once a week until 12 weeks following transplantation. To avoid the detrimental effects of sunlight, the therapy is administered in the evening, immediately before sunset (about 4:30 pm) (Gozel and Kasap, 2015). Using a knapsack spray, the spray dose for each treatment was 1000 L ha-1 (Brusselman et al., 2012). EPNs were treated with the dosages used (Gozel and Kasap, 2015; Kamali et al., 2018). During treatment, a constant noise is generated to keep water rain from falling.

\section{Statistical analysis}

Insect mortality was regulated (Abbott 1925) and the roots of the square were modified where necessary to meet common perceptions and diversity. In all trials, randomized controlled trials were reduced in the multivariate analysis (ANOVA) and mean classification of the LSD test (OPSTAT software 2021).

Bioassay and EPN experiments in tropical conditions, T. absoluta mortality inside or outside the tomato leaf were analyzed by one-way covariance analyzes (ANOVA) where EPN species were considered the main ones and the total number of tomato leaf leaves was classified as a covariate. Mortality data during the one-way and completely randomized construction followed by several Tukey comparative tests $(P<0.05)$

\section{Results}

\section{Efficacy of Lab bioassay}

The largest larval mortality was recorded in 3rd instar T. absoluta larvae, and the therapy was superior. The treatment with $\mathrm{H}$. indica at $160 \mathrm{IJs} / \mathrm{cm} 2 \mathrm{resulted}$ in the highest percent larvae mortality, with 90.00 percent larval mortality, followed by $S$. feltiae at $160 \mathrm{IJs} / \mathrm{cm}^{2}$ ( 85.38 percent). The next best treatments, in order of efficacy, were $H$. indica at $80 \mathrm{IJs} / \mathrm{cm}^{2}$ (74.12 percent), S. feltiae at $80 \mathrm{IJs} / \mathrm{cm}^{2}$ (69.50 percent), and $H$. indica at $80 \mathrm{IJs} / \mathrm{cm}^{2}$ (74.12 percent) (Table 2). The mortality rate of larvae ranged from 31.53 to 90.00 percent. The highest larval mortality of 4th instar $T$. absoluta larvae was recorded, and it was discovered to be the most superior treatment. The treatment with $S$. feltiae at $160 \mathrm{IJs} / \mathrm{cm}^{2}$ resulted in the highest percent larvae mortality, with 90.00 percent larval mortality, followed by $\mathrm{H}$. indica at $160 \mathrm{IJs} / \mathrm{cm}^{2}$ (80.76 percent) (Fig. 4). The next best treatments, in order of efficacy, were S. feltiae at $80 \mathrm{IJs} / \mathrm{cm}^{2}$ (74.12 percent), $H$. indica at $80 \mathrm{IJs} / \mathrm{cm}^{2}$ (67.84 percent), and $\mathrm{H}$. indica at $80 \mathrm{IJs} / \mathrm{cm}^{2}$ (67.84 percent) (Table 2).

\section{Bioassay of larvicidal activity}

Tuta absoluta $3^{\text {rd }}$ instar larvae had $\mathrm{LC}_{50}$ of $19.29 \mathrm{IJs} / \mathrm{cm}^{2}, 08.55 \mathrm{IJs} / \mathrm{cm}^{2}, \mathrm{LC}_{75}$ of IJs/cm², $83.12 \mathrm{IJs} / \mathrm{cm}^{2}, 40.47 \mathrm{IJs} / \mathrm{cm}^{2}$, and LC 90 of IJs/cm², $50.44 \mathrm{IJs} / \mathrm{cm}^{2}$, $78.89 \mathrm{IJs} / \mathrm{cm}^{2}$, respectively, for 48 hours. $\mathrm{LC}_{50}$ of $07.52 \mathrm{IJs} / \mathrm{cm}^{2}, 05.42 \mathrm{IJs} / \mathrm{cm}^{2}, \mathrm{LC}_{75}$ of $25.42 \mathrm{IJs} / \mathrm{cm}^{2}, 20.70 \mathrm{lJs} / \mathrm{cm}^{2}$, and LC 90 of $26.03 \mathrm{lJs} / \mathrm{cm}^{2}, 69.19$

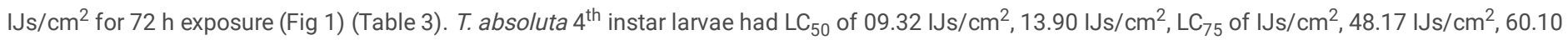
$\mathrm{IJs} / \mathrm{cm}^{2}$, and $\mathrm{LC}_{90}$ of $\mathrm{IJs} / \mathrm{cm}^{2}, 74.18 \mathrm{IJs} / \mathrm{cm}^{2}, 76.43 \mathrm{IJs} / \mathrm{cm}^{2}$, respectively, for 48 hours. $\mathrm{LC}_{50}$ of $05.89 \mathrm{IJs} / \mathrm{cm}^{2}, 08.92 \mathrm{IJs} / \mathrm{cm}^{2}, \mathrm{LC}_{75}$ of $20.29 \mathrm{IJs} / \mathrm{cm}^{2}, 32.61$ $\mathrm{IJs} / \mathrm{cm}^{2}$, and $\mathrm{LC}_{90}$ of $61.71 \mathrm{JJs} / \mathrm{cm}^{2}, 56.63 \mathrm{lJs} / \mathrm{cm}^{2}$ for $72 \mathrm{~h}$ exposure (Fig 2) (Table 3).

\section{Table 2}

Larvicidal activity of tested nematode strain against tomato pinworm $3^{\text {rd }}$ and $4^{\text {th }}$ instar larva stage mortality (\%) mean performance 
$3^{\text {rd }}$ Instar of Tuta absoluta

Tuta absoluta mortality (\%) $24 \mathrm{hrs}$ after treatment

\begin{tabular}{|c|c|c|c|c|c|c|c|c|c|c|c|c|c|}
\hline \multirow[t]{2}{*}{ Treatment } & \multicolumn{3}{|c|}{ Steinemema feltiae } & \multicolumn{3}{|c|}{ Heterorhabditis indica } & \multirow[t]{2}{*}{ Mean } & \multicolumn{3}{|c|}{ Steinemema feltiae } & \multicolumn{3}{|c|}{ Heterorhabditis indica } \\
\hline & $24 \mathrm{hrs}$ & $48 \mathrm{hrs}$ & 72 hrs & $24 \mathrm{hrs}$ & $48 \mathrm{hrs}$ & $72 \mathrm{hrs}$ & & 24 hrs & $48 \mathrm{hrs}$ & $72 \mathrm{hrs}$ & $24 \mathrm{hrs}$ & $48 \mathrm{hrs}$ & 72 \\
\hline \multirow[t]{2}{*}{ Control } & 0.00 & 0.00 & 0.00 & 0.00 & 0.00 & 0.00 & 0.00 & 0.00 & 0.00 & 0.00 & 0.00 & 0.00 & 0.0 \\
\hline & $(0.00)^{*}$ & $(0.00)$ & $(0.00)$ & $(0.00)$ & $(0.00)$ & $(0.00)$ & $(0.00)$ & $(0.00)$ & $(0.00)$ & $(0.00)$ & $(0.00)$ & $(0.00)$ & $(0.1$ \\
\hline \multirow{2}{*}{$\begin{array}{l}10 \\
\mathrm{IJs} / \mathrm{cm}^{2}\end{array}$} & 17.50 & 37.50 & 57.50 & 30.00 & 55.00 & 65.00 & 43.75 & 30.00 & 50.00 & 60.00 & 27.50 & 42.50 & 52. \\
\hline & $(24.15)$ & $(37.64)$ & $(49.30)$ & (33.04) & $(47.86)$ & $(53.75)$ & $(40.95)$ & $(33.04)$ & $(44.98)$ & $(50.87)$ & $(31.53)$ & (40.59) & $(46$ \\
\hline \multirow{2}{*}{$\begin{array}{l}20 \\
\mathrm{IJs} / \mathrm{cm}^{2}\end{array}$} & 27.50 & 50.00 & 70.00 & 40.00 & 62.50 & 72.50 & 53.75 & 42.50 & 62.50 & 77.50 & 42.50 & 57.50 & 67. \\
\hline & (31.38) & (44.98) & (56.92) & (39.15) & (52.31) & $(58.58)$ & $(47.22)$ & (40.65) & (52.25) & $(61.74)$ & $(40.59)$ & (49.30) & (55 \\
\hline \multirow{2}{*}{$\begin{array}{l}40 \\
\mathrm{IJs} / \mathrm{cm}^{2}\end{array}$} & 45.00 & 65.00 & 82.50 & 50.00 & 75.00 & 82.50 & 66.66 & 50.00 & 75.00 & 85.00 & 50.00 & 67.50 & 77. \\
\hline & (42.03) & $(53.75)$ & $(65.44)$ & (44.98) & $(60.61)$ & $(68.76)$ & (55.92) & (44.98) & $(60.24)$ & $(67.47)$ & (44.98) & (55.26) & (61 \\
\hline \multirow{2}{*}{$\begin{array}{l}80 \\
\mathrm{IJs} / \mathrm{cm}^{2}\end{array}$} & 55.00 & 75.00 & 87.50 & 62.50 & 80.00 & 90.00 & 75.00 & 57.50 & 80.00 & 90.00 & 60.00 & 75.00 & 85. \\
\hline & $(47.86)$ & $(60.08)$ & $(69.50)$ & (52.31) & (63.78) & (74.12) & $(61.27)$ & (49.37) & (66.73) & (74.12) & $(50.81)$ & $(60.24)$ & $(67$ \\
\hline \multirow{2}{*}{$\begin{array}{l}160 \\
\mathrm{IJs} / \mathrm{cm}^{2}\end{array}$} & 65.00 & 82.50 & 97.50 & 75.00 & 92.50 & 100.00 & 85.41 & 67.50 & 87.50 & 100.00 & 72.50 & 87.50 & 95. \\
\hline & (53.91) & $(65.44)$ & (85.38) & $(60.08)$ & (76.15) & $(90.00)$ & (71.82) & $(55.26)$ & (72.46) & $(90.00)$ & $(58.42)$ & $(69.50)$ & $(80$ \\
\hline \multirow[t]{2}{*}{ Mean } & 35.00 & 51.66 & 65.83 & 42.91 & 60.83 & 68.33 & & 41.21 & 59.16 & 68.75 & 42.08 & 55.00 & 62. \\
\hline & (33.22) & $(43.65)$ & $(54.42)$ & (38.26) & $(50.12)$ & (57.53) & & $(37.21)$ & $(49.44)$ & (57.36) & (37.72) & (45.81) & (52 \\
\hline $\begin{array}{l}\text { LSD }(p< \\
0.05)\end{array}$ & 9.03 & 6.68 & 7.56 & 6.66 & 9.55 & 12.59 & & 6.05 & 13.76 & 8.77 & 6.08 & 6.28 & 9.0 \\
\hline
\end{tabular}

*Figures in parentheses are arc sine transformed values

Table 3.

Log probit analysis of larvicidal activity of tested nematode strain against tomato pinworm instars, $3^{\text {rd }}$ and $4^{\text {th }}$ stage

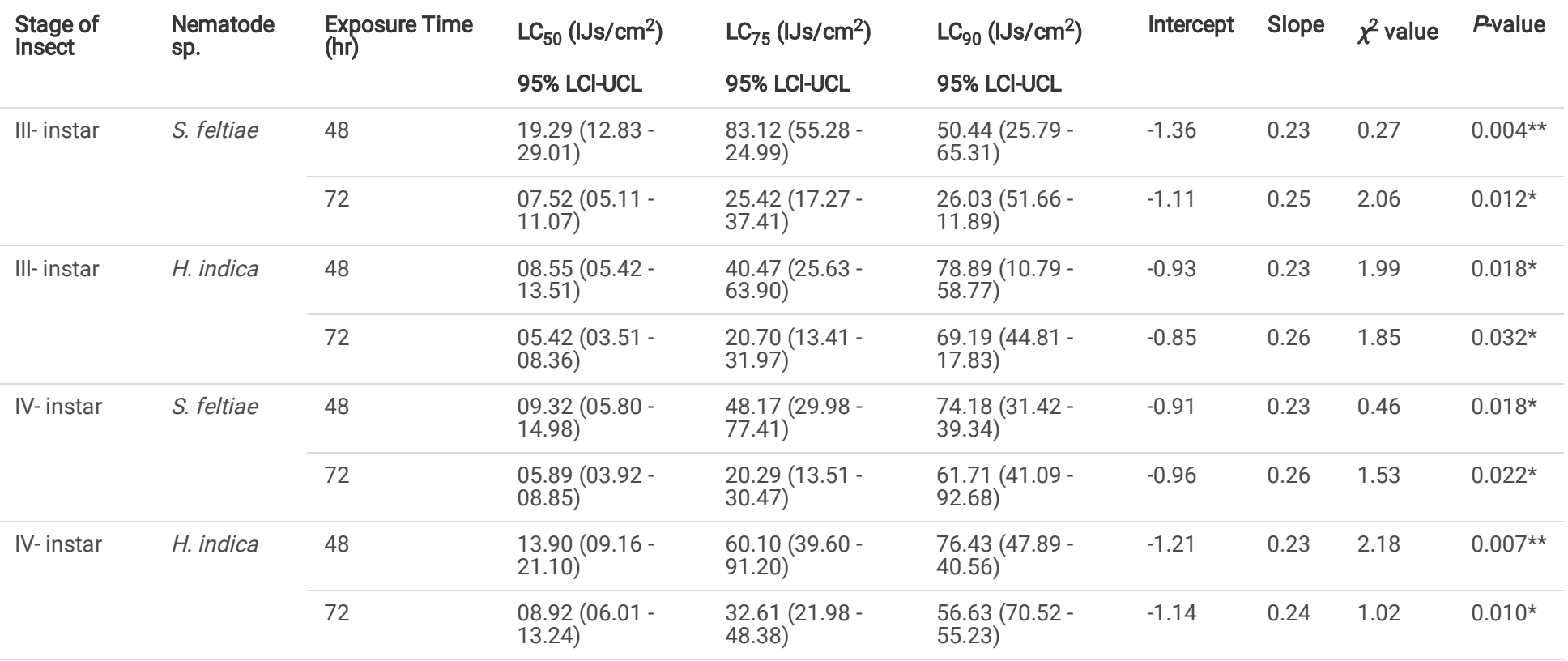

- EPNs suspensions were administered at a concentration of (IJs/cm2).

- Lethal Concentration are calculated by Probit Methods.

- Significant differences from control are indicated $\left(* \star P<0.01\right.$; $\left.{ }^{*} P<0.05\right)$. 


\section{Efficacy of Greenhouse Tests}

The survival population of the tomato leafminer Tuta absoluta on tomato one day before, three, seven, ten, and fourteen days after the first spray was presented in (Table 2). The average number of T. absoluta larvae that survived one day before being sprayed ranged from 5.77 to 7.36 larvae per plant. The pre-treatment data was determined to be non-significant, indicating that the pest population in the experimental plot was uniform. A small increase in the larval population was seen in all treated plots 14 days after the first spray. The average number of larvae that survived each plant ranged from 1.31 to 2.13 . The maximum number of larvae per plant was found in the untreated control plot, which had 4.09 larvae per plant. Treatment with $H$. indica at $1,00,000$ $\mathrm{IJs} / \mathrm{cm}^{2}$ (1.31 larvae/plant) was shown to be consistently effective against $T$. absoluta, followed by treatment with $H$. indica at $2,00,000 \mathrm{IJs} / \mathrm{cm}^{2}$ (1.42 larvae/plant). Treatments with $S$. feltiae at $1,00,000 \mathrm{IJs} / \mathrm{cm}^{2}$ (1.59 larvae/plant) and $S$. feltiae at 2,00,000 IJs/cm2 (1.68 larvae/plant) were the next in order of efficacy, with no significant differences between them.

Overall, the efficacy results showed that $H$. indica at $1,00,000 \mathrm{IJs} / \mathrm{cm}^{2}(1.78$ larvae/plant) was the most successful treatment in lowering the $T$. absoluta surviving population when compared to other treatments. The next most successful treatment was $S$. feltiae at a rate of $1,00,000 \mathrm{IJs} / \mathrm{cm}^{2}(1.97 \mathrm{larvae} / \mathrm{plant})$. In order of efficacy, $\mathrm{H}$. indica was next with $2,00,000 \mathrm{IJs} / \mathrm{cm}^{2}(2.00$ larvae/plant). A small increase in the larval population was seen in all of the treated plots 14 days after the second spray. The average number of larvae survival populations per plant ranged from 1.18 to 1.51 . It was found to be the highest in the untreated control plot, with 4.24 larvae per plant. Treatment with $H$. indica at 2,00,000 IJs/ $\mathrm{cm}^{2}$ (1.18 larvae/plant) was shown to be consistently effective against T. absoluta, as was treatment with $S$. feltiae at 2,00,000 IJs/ $\mathrm{cm}^{2}\left(1.38\right.$ larvae/plant). Treatments with $H$. indica at $1,00,000 \mathrm{IJs} / \mathrm{cm}^{2}(1.45 \mathrm{larvae} / \mathrm{plant})$, $H$. indica at $4,00,000 \mathrm{IJs} / \mathrm{cm}^{2}$ (1.48 larvae/plant), and $H$. indica at $4,00,000 \mathrm{IJs} / \mathrm{cm}^{2}$ (1.48 larvae/plant) were the next in order of efficacy, and there were no significant differences in the remaining treatments.

Thus, the treatment with $H$. indica at 2,00,000 IJs/ $\mathrm{cm}^{2}\left(1.60\right.$ larvae/plant) was shown to be superior than $H$. indica at $1,00,000 \mathrm{IJs} / \mathrm{cm}^{2}(1.66$ larvae/plant) and $H$. indica at 4,00,000 IJs/ $\mathrm{cm}^{2}$ (1.77 larvae/plant) in terms of overall performance. $S$. feltiae at 1,00,000 IJs/cm ${ }^{2}(1.84 \mathrm{larvae} / \mathrm{plant}), S$. feltiae at $2,00,000 \mathrm{IJs} / \mathrm{cm}^{2}$ (1.85 larvae/plant), and $S$. feltiae at $4,00,000 \mathrm{IJs} / \mathrm{cm}^{2}$ (2.06 larvae/plant) were all shown to be similarly effective in lowering the $T$. absoluta population. A small increase in the larval population was seen in all of the treated plots at 14 DAS of the third spray. The average number of larvae survival populations per plant ranged from 1.02 to 1.98 . The maximum number of larvae per plant was found in the untreated control plot, at 4.92 . Treatment with $H$. indica at $4,00,000 \mathrm{IJs} / \mathrm{cm}^{2}$ (1.02 larvae/plant) was shown to be consistently effective against $T$. absoluta, as did treatment with $H$. indica at 2,00,000 $\mathrm{IJs} / \mathrm{cm}^{2}$ (1.09 larvae/plant). Treatments with $S$. feltiae at 2,00,000 IJs/ $\mathrm{cm}^{2}$ (1.17 larvae/plant), S. feltiae at 1,00,000 IJs/cm ${ }^{2}(1.34 \mathrm{larvae} / \mathrm{plant})$, and S. feltiae at $4,00,000 \mathrm{IJs} / \mathrm{cm}^{2}$ (1.53 larvae/plant) were found to be equally successful, as were treatments with $H$. indica at $1,00,000 \mathrm{IJs} / \mathrm{cm}^{2}$. The treatments, on the other hand, produced 4.92 larvae per plant compared to 4.92 larvae per plant in the untreated control.

After the third spray, the overall performance of the various treatments revealed that the $H$. indica treatment at $4,00,000 \mathrm{IJs} / \mathrm{cm}^{2}$ was consistently most effective and superior to the other treatments, with the lowest larval population ( 1.17 larvae/plant) compared to 4.48 larvae/plant in the untreated control. The next most effective treatment was $H$. indica at a concentration of 2,00,000 IJs/ $\mathrm{cm}^{2}$ (1.34 larvae/plant). Significant differences between the treatments were not identified, with $S$. feltiae at $2,00,000 \mathrm{IJs} / \mathrm{cm}^{2}\left(1.60\right.$ larvae/plant) and $S$. feltiae at $4,00,000 \mathrm{IJs} / \mathrm{cm}^{2}(1.65$ larvae/plant) being on par. $S$. feltiae at $1,00,000$ $\mathrm{IJs} / \mathrm{cm}^{2}$ (1.83 larvae/plant) and $H$. indica at $2,00,000 \mathrm{IJs} / \mathrm{cm}^{2}$ (2.25 larvae/plant) treatments were shown to be somewhat efficient in lowering the surviving $T$. absoluta population. After three sprayings, the overall results of the current experiment demonstrated that among the entomopathogenic agents, $H$. indica at $2,00,000 \mathrm{IJs} / \mathrm{cm}^{2}$ was consistently effective against $T$. absoluta, with the lowest larvae population (1.64 Larvae/plant). $H$. indica at 4,00,000 IJs/cm ${ }^{2}$ and $S$. feltiae at 1,00,000 IJs/ $\mathrm{cm}^{2}$, as well as $S$. feltiae at 2,00,000 IJs/ $\mathrm{cm}^{2}$, produced greater results against $T$. absoluta.

\section{Table 4.}

Efficacy of entomopathogenic nematode against Tuta absoluta in tomato crop (overall effect of three sprays). 


\begin{tabular}{|c|c|c|c|c|c|c|c|c|c|c|c|c|c|c|c|c|}
\hline \multirow{3}{*}{$\begin{array}{l}\text { Sr. } \\
\text { No }\end{array}$} & \multirow{3}{*}{ Treatments } & \multirow{3}{*}{$\begin{array}{l}\text { Dose } \\
\mathrm{IJs} / \mathrm{m}^{2}\end{array}$} & \multirow{3}{*}{$\begin{array}{l}\text { Pre } \\
\text { count }\end{array}$} & \multirow{2}{*}{\multicolumn{4}{|c|}{$\begin{array}{l}1^{\text {st }} \text { Spray } \\
\begin{array}{l}\text { Mean survival population of Tuta } \\
\text { absoluta larvae/plant }\end{array}\end{array}$}} & \multirow{3}{*}{ Mean } & \multirow{2}{*}{\multicolumn{4}{|c|}{$\begin{array}{l}2^{\text {nd }} \text { Spray } \\
\text { Mean survival population of Tuta } \\
\text { absoluta larvae/plant }\end{array}$}} & \multirow{3}{*}{ Mean } & \multirow{2}{*}{\multicolumn{3}{|c|}{$\begin{array}{l}3^{\text {rd }} \text { Spray } \\
\text { Mean survival popi } \\
\text { absoluta larvae/pla }\end{array}$}} \\
\hline & & & & & & & & & & & & & & & & \\
\hline & & & & $\begin{array}{l}3 \\
\text { DAS }\end{array}$ & $\begin{array}{l}7 \\
\text { DAS }\end{array}$ & $\begin{array}{l}10 \\
\text { DAS }\end{array}$ & $\begin{array}{l}14 \\
\text { DAS }\end{array}$ & & $\begin{array}{l}3 \\
\text { DAS }\end{array}$ & $\begin{array}{l}7 \\
\text { DAS }\end{array}$ & $\begin{array}{l}10 \\
\text { DAS }\end{array}$ & $\begin{array}{l}14 \\
\text { DAS }\end{array}$ & & $\begin{array}{l}3 \\
\text { DAS }\end{array}$ & $\begin{array}{l}7 \\
\text { DAS }\end{array}$ & $\begin{array}{l}1 \\
{[}\end{array}$ \\
\hline \multirow[t]{2}{*}{1} & S. feltiae & $1,00,000$ & 5.77 & 2.417 & 2.16 & 1.72 & 1.59 & 1.97 & 2.15 & 1.92 & 1.79 & 1.51 & 1.84 & 2.66 & 1.70 & 1 \\
\hline & & & $(2.60)^{\star}$ & $(1.84)$ & (1.77) & $(1.64)$ & $(1.60)$ & $(1.71)$ & (1.77) & $(1.70)$ & $(1.67)$ & (1.58) & (1.68) & (1.91) & $(1.64)$ & ( \\
\hline \multirow[t]{2}{*}{2} & S. feltiae & $2,00,000$ & 6.52 & 2.677 & 2.36 & 2.05 & 1.68 & 2.19 & 2.12 & 2.10 & 1.80 & 1.38 & 1.85 & 1.83 & 1.76 & 1 \\
\hline & & & $(2.74)$ & $(1.91)$ & $(1.83)$ & $(1.74)$ & $(1.63)$ & $(1.77)$ & $(1.76)$ & $(1.76)$ & $(1.67)$ & $(1.54)$ & (1.68) & $(1.68)$ & $(1.66)$ & ( \\
\hline \multirow[t]{2}{*}{3} & S. feltiae & $4,00,000$ & 6.90 & 2.74 & 2.40 & 2.34 & 2.07 & 2.38 & 2.17 & 2.12 & 2.12 & 1.83 & 2.06 & 1.58 & 1.74 & 1 \\
\hline & & & $(2.80)$ & $(1.93)$ & $(1.84)$ & $(1.82)$ & $(1.75)$ & $(1.83)$ & $(1.78)$ & $(1.76)$ & $(1.76)$ & $(1.68)$ & (1.74) & $(1.60)$ & $(1.65)$ & ( \\
\hline \multirow[t]{2}{*}{4} & H. indica & $1,00,000$ & 7.20 & 2.317 & 2.06 & 1.44 & 1.31 & 1.78 & 1.87 & 1.56 & 1.77 & 1.45 & 1.66 & 2.59 & 2.31 & 2 \\
\hline & & & $(2.85)$ & $(1.82)$ & $(1.75)$ & $(1.56)$ & $(1.51)$ & $(1.66)$ & (1.69) & $(1.60)$ & $(1.66)$ & $(1.56)$ & (1.62) & (1.89) & $(1.82)$ & ( \\
\hline \multirow[t]{2}{*}{5} & H. indica & $2,00,000$ & 6.51 & 2.577 & 2.19 & 1.84 & 1.42 & 2.00 & 1.74 & 1.81 & 1.68 & 1.18 & 1.60 & 1.64 & 1.43 & 1 \\
\hline & & & $(2.73)$ & $(1.89)$ & (1.78) & $(1.68)$ & (1.55) & $(1.72)$ & (1.65) & $(1.67)$ & (1.63) & $(1.47)$ & (1.60) & $(1.62)$ & (1.56) & ( \\
\hline \multirow[t]{2}{*}{6} & H. indica & $4,00,000$ & 6.21 & 2.64 & 2.26 & 2.14 & 2.13 & 2.29 & 1.74 & 1.83 & 2.05 & 1.48 & 1.77 & 1.41 & 1.17 & \\
\hline & & & $(2.68)$ & $(1.90)$ & $(1.80)$ & $(1.77)$ & $(1.76)$ & $(1.80)$ & (1.65) & $(1.68)$ & (1.74) & $(1.57)$ & (1.66) & (1.55) & $(1.42)$ & ( \\
\hline \multirow[t]{4}{*}{7} & Control & \multirow{2}{*}{$\begin{array}{l}\text { Water } \\
\text { Spray }\end{array}$} & 7.36 & 3.53 & 3.87 & 4.08 & 4.09 & 3.89 & 3.79 & 4.03 & 4.28 & 4.24 & 4.08 & 4.16 & 4.23 & 2 \\
\hline & & & $(2.88)$ & $(2.12)$ & $(2.20)$ & $(2.25)$ & $(2.25)$ & $(2.20)$ & (2.19) & $(2.24)$ & $(2.29)$ & $(2.28)$ & $(2.25)$ & $(2.27)$ & $(2.28)$ & ( \\
\hline & SE \pm & & N/A & 0.02 & 0.01 & 0.04 & 0.05 & & 0.007 & 0.01 & 0.01 & 0.01 & & 0.02 & 0.02 & $i$ \\
\hline & CD at $5 \%$ & & 0.08 & 0.06 & 0.05 & 0.14 & 0.16 & & 0.02 & 0.05 & 0.05 & 0.05 & & 0.07 & 0.07 & ( \\
\hline
\end{tabular}

*Figures in parentheses are transformed values Öx+ 0.5

Table 5.

Efficacy of entomopathogenic nematode against Tuta absoluta in tomato crop (overall effect of three sprays). 


\begin{tabular}{|c|c|c|c|c|c|c|c|}
\hline Sr. No & Treatments & $\begin{array}{l}\text { Dose } \\
\left(\mathrm{IJs} / \mathrm{m}^{2}\right)\end{array}$ & Pre count & First spray mean & Second spray mean & Third spray mean & Overall mean \\
\hline \multirow[t]{2}{*}{1} & S. feltiae & $1,00,000$ & 5.77 & 1.97 & 1.84 & 1.83 & 1.88 \\
\hline & & & $(2.60)$ * & $(1.71)$ & $(1.68)$ & $(1.67)$ & $(1.68)$ \\
\hline \multirow[t]{2}{*}{2} & S. feltiae & $2,00,000$ & 6.52 & 2.19 & 1.85 & 1.60 & 1.88 \\
\hline & & & $(2.74)$ & $(1.77)$ & $(1.68)$ & $(1.60)$ & $(1.68)$ \\
\hline \multirow[t]{2}{*}{3} & S. feltiae & $4,00,000$ & 6.90 & 2.38 & 2.06 & 1.65 & 2.03 \\
\hline & & & $(2.80)$ & $(1.83)$ & $(1.74)$ & $(1.62)$ & $(1.73)$ \\
\hline \multirow[t]{2}{*}{4} & H. indica & $1,00,000$ & 7.20 & 1.78 & 1.66 & 2.25 & 1.89 \\
\hline & & & $(2.85)$ & $(1.66)$ & $(1.62)$ & $(1.79)$ & $(1.69)$ \\
\hline \multirow[t]{2}{*}{5} & H. indica & $2,00,000$ & 6.51 & 2.00 & 1.60 & 1.34 & 1.64 \\
\hline & & & $(2.73)$ & $(1.72)$ & $(1.60)$ & $(1.52)$ & $(1.61)$ \\
\hline \multirow[t]{2}{*}{6} & H. indica & $4,00,000$ & 6.21 & 2.29 & 1.77 & 1.17 & 1.74 \\
\hline & & & $(2.68)$ & $(1.80)$ & $(1.66)$ & $(1.45)$ & (1.63) \\
\hline \multirow[t]{4}{*}{7} & Control & Water Spray & 7.36 & 3.89 & 4.08 & 4.48 & 4.15 \\
\hline & & & $(2.88)$ & $(2.20)$ & $(2.25)$ & $(2.33)$ & $(2.26)$ \\
\hline & SE \pm & & $\mathrm{N} / \mathrm{A}$ & 0.03 & 0.02 & 0.03 & 0.05 \\
\hline & $\mathrm{CD}$ at $5 \%$ & & 0.08 & 0.11 & 0.08 & 0.11 & 0.16 \\
\hline
\end{tabular}

DAS = Days after spray

*Figures in parentheses are transformed values Öx+ 0.5

\section{Discussion}

Possibility of using with a stand, entomopathogenic to T. absoluta. Because laboratory operations do not have to take care of the field of work, workplace validation was discussed in the next section (Lacey et al., 2015; Ndereyimana et al., 2019a, 2019b, c). EPNs can detect and kill larvae in tomato leaves as well. A high level of worm infection (77.1-91.7 percent) was recorded in a leaf bioassay produced in laboratory circumstances (Batalla-Carrera et al., 2010), showing the agents' capacity to kill worms within the plant. This is because all leaf litter larvae contain holes through which EPNs can enter and kill the larvae.

Under field conditions, high-performance EPN field performance was produced and compared to T. absoluta (Shams-al-Din et al., 2014; Gozel and Kasap, 2015). (Batla-Carella et al., 2010) Furthermore, EPN is already in use as a paper application in other factories. A variety of other insects (Mahmud, 2016). The capabilities of recognized EPNs can be connected to their performance. T. absoluta, where they are protected from the harsh environment (Batala-carella et al., 2010; Kamali et al., 2018). It appears to be T. absoluta larvae. EPs IJs have been shown to have the ability to survive and reproduce in a variety of conditions (Elien, 2018). Furthermore, the suitable Steinernema EPNs' efficiency can be related to their genetic variants (Xenorhabdus) and deceptive catchers, the Ambusher Strategy, which patiently awaits their manager (Mahmoud, 2016).

The involvement of T. absoluta at Steinernema monticolum Stock, Choo \& Kaya, and H. bacteriophora (HP88) was determined in the laboratory and in the field in another series of research (Shamseldean et al., 2014). Laboratory-operated leaves of both nematodes display high levels of aggression in bioassays (80100 percent mortality). For field testing done over three years, foliar spraying of two types of EPNs demonstrated a death rate of 60-80 percent $T$. absoluta death rate of $H$. bacteriophora as a result, the authors conclude that $H$. bacteriophora (HP88) was more potent than S. monticolum in both the lab and in the field than T. absoluta (Shamseldean et al., 2014).

Application of EPN to the soil to suppress last instar larvae as they drop from leaves to pupae, as well as adults emerging from buried pupae, may be a complementing technique to foliar treatment of $T$. absoluta. soil treatment efficacy $T$. absoluta larvae, pupae, and adults were tested in the laboratory against three native entomopathogenic nematodes (S. carpocapsae, S. feltiae, and H. bacteriophora) (Garcia-del-Pino et al., 2013).

T-ground EPN applications have a lot of power. It is critical to fully manage and comprehend the effects of various substrates often used to grow tomatoes. Although outcomes may vary with EPN types, it is known that soil type and texture might affect EPN performance and persistence (Kaya, 1990). (Koppenhofer and Fuzy 2006). Unavailability was found to diminish as the amount of carved soil was reduced in various investigations (Campos-Herrera and Gutierrez, 2009; Hassani Kakhki et al., 2012). However, both forms of EPN induced more depth in our sample than fertile sand (89\%) and sandy loam (17\%); such a substantial variation was not predicted given the differing perceptions of composition, $\mathrm{pH}$, and carbon content. In earlier research, several types of EPNs species, notably H. bacteriophora, have shown excellent performance on the highest substrate, as in our study (sand soil, 93 percent) (Koppenhofer and Fuzy, 2006). 
Overall, the product appears to fit the requirements of these EPNs to achieve large levels of Tuta absoluta infection due to the natural conditions of tomatoes keeping it warm. With $50 \%$ control of both species, our thermal study indicated the strong inclination of caterpillar T. absoluta H. bacteriophora and S. feltiae. It is strongly suggested if you consider the high relative humidity level required by EPN for spray treatments (Portman et al., 2016). Before insect infestation reaches these high altitudes, EPNs biocontrol agents should be used. The findings of this investigation reveal that $H$. bacteriophora and $S$. feltiae are both comparable to H. bacteriophora (Ebssa et al., 2004, Rezaei et al., 2015).

\title{
Conclusions
}

Invasive species pose a significant threat, as evidenced by this research. Traditional EPNs (S. feltiae HR-1, H. indica HA-2) have been used as an active biocontrol agent in laboratory and greenhouse settings, as well as the pathogen that infects $T$. absoluta. Overall, the natural conditions of heat-retaining tomatoes appear to match the EPNs' requirements for achieving high T. absoluta infection levels. The T. absoluta steep inclination was confirmed in our greenhouse testing. With 50\% control over both EPNs strains, S. feltiae HR-1 and H. indica HA-2 were used.

\section{Abbreviations}

\author{
EPNs \\ Entomopathogenic nematodes \\ IJs \\ Infective Juveniles \\ $\mathrm{cm}^{2}$ \\ Centimetre square \\ Ib \\ Pound \\ $\mathrm{LD}_{50}$ \\ Median lethal dose \\ OPSTAT \\ Operational Status \\ $\mathrm{h}$ \\ Hour \\ LSD \\ Least significant difference \\ (HR-1) \\ Isolate number one \\ (HA-2) \\ Isolate number two.
}

\section{Declarations}

\section{Acknowledgements.}

We would like to acknowledge the Dr. Yashwant Singh Parmar University of Horticulture and Forestry, Nauni, Solan, HP, India-173230 for support of this research. And Indian council of Agricultural Research (ICAR) for providing necessary facilities and financial support, respectively We are also grateful to Department of entomology, Nematology laboratory used in this study.

\section{Authorship contribution statement}

All authors jointly designed the experiment. KI conducted the laboratory bioassays, performed data analysis and drafted the manuscript with inputs from all authors. MS, MW and PS collaborated closely with KI in the whole process especially during data analysis. All authors read and approved the final manuscript.

\section{Competing Interest}

The authors declare that they have no known competing financial interests or personal relationships that could have appeared to influence the work reported in this paper.

\section{Availability of data and materials}

All data generated or analysed during this study are included in this published article

\section{References}

1. Abbas W., Javed N., Haq I.U., Ahmed S. (2021). Pathogenicity of entomopathogenic nematodes against cabbage butterfly (Pieris brassicae) Linnaeus (Lepidoptera: Pieridae) in laboratory conditions. Int J Trop Insect Sci, 41, 525-531. https://doi.org/10.1007/s42690-020-00236-2. 
2. Arthurs S., Heinz K.M., Prasifka J.R. (2004). An analysis of using entomopathogenic nematodes against above-ground pests. Bulletin of Entomological Research, 94, 297-306. https://doi.org/10.1079/BER2003309.

3. Ballal C.R., Gupta A., Mohan M., Lalitha Y., Verghese A. (2016). The new invasive pest Tuta absoluta (Meyrick) (Lepidoptera: Gelechiidae) in India and its natural enemies along with evaluation of Trichogrammatids for its biological control. Curr Sci, 110, 2155-2159. https://doi.org/10.18520/cs/v110/i11/2155-2159.

4. Belien T. (2018). Entomopathogenic nematodes as biocontrol agents of insect pests in orchards. CAB Rev 13. https://doi.org/10.1079/PAVSNNR201813058, 058.

5. Bielza P. (2010). Resistance to insecticides in Tuta absoluta (Meyrick). Phytoma Espana 217, 103-106. ISSN: 1131-8988.

6. CABI. (2018). Tuta absoluta. In: Invasive Species Compendium. Wallingford, UK: CAB International. Retreived from: .

7. Campos-Herrera R., Gutierrez C. (2009). Screening Spanish isolates of steinernematid nematodes for use as biological control agents through laboratory and greenhouse microcosm studies. J. Invertebr. Pathol, 100, 100-105. https://doi.org/10.1016/j.jip.2008.11.009.

8. Desneux N., Wajnberg E., Wyckhuys K.A.G., Burgio G., Arpaia S., Narva 'ez-Vasquez C.A, Gonza 'lez., Cabrera J., Catala n Ruescas D., Tabone E., Frandon J., Pizzol J., Poncet C., Cabello T., Urbaneja A. (2010). Biological invasion of European tomato crops by Tuta absoluta: ecology, history of invasion and prospects for biological control. J Pest Sci, 83, 197-215. https://doi.org/10.1007/s10340-010-0321-6.

9. Ebssa L., Borgemeister C., Poehling H.M. (2004). Effectiveness of different species/strains of entomopathogenic nematodes for control of western flower thrips (Frankliniella occidentalis) at various concentrations, host densities, and temperatures. Biol Control, 29, 145-154. https://doi.org/10.1016/S10499644(03)00132-4.

10. Forst S., Clarke D. (2002). Bacteria-nematode symbiosis. In: Gaugler, R. (Ed.), Entomopathogenic Nematology. CABI Publishing, New York, USA, pp. 5777. ISBN 0851995675.

11. Garcia-del-Pino F., Alabern X., Morton A. (2013). Efficacy of soil treatments of entomopathogenic nematodes against the larvae, pupae and adults of Tuta absoluta and their interaction with the insecticides used against this insect. BioControl, 58, 723-731. https://doi.org/10.1007/s10526-013-9525-Z.

12. Gavkare O., Sharma P.L. (2017). Influence of temperature on development of Nesidiocoris tenuis (Reuiter) preying on Trialeurodes vaporariorum (Westwood) on tomato. Entomol News, 127(3): 230-41. https://doi.org/10.3157/021.127.0306

13. Gozel C., Kasap I. (2015). Efficacy of entomopathogenic nematodes against the Tomato leafminer, Tuta absoluta (Meyrick) (Lepidoptera: Gelechiidae) in tomato field. Turk. Entomol. Derg, 39, 229-237. https://doi.org/10.16970/ted.84972.

14. Grewal P.S., Ehlers R.U., Shapiro-Ilan D.I. (2005). Nematodes as Biocontrol Agents. CABI Publishing, Wallingford, UK. ISBN 0851990177.

15. Hassani-Kakhki M., Karimi J., Hosseini M. (2012). Efficacy of entomopathogenic nematodes against potato tuber moth, Phthorimaea operculella (Lepidoptera: Gelechiidae) under laboratory conditions. Biocontrol, Sci. Tech. 23, 146-159. https://doi.org/10.1080/09583157.2012.745481.

16. Ingegno B.L., Feracini C., Gallinotti D., Alma A., Tavella L. (2013). Evaluation of the effectiveness of Dicyphus errans (Wolff) as predator of Tuta absoluta (Meyrick). Biol Control, 67, 246-52. https://doi.org/10.1016/j.biocontrol.2013.08.002.

17. Ju R.T., Wang F., Li B. (2011). effects of temperature on the development and population growth of the Sycamore lace bug, Corythucha ciliata. J Insect Sci, 11, 16. https://doi.org/10.1673/031.011.0116.

18. Kajuga J., Hategekimana A., Yan X., Waweru B.W., Li H., Li K. (2018). Management of white grubs (Coleoptera: Scarabeidae) with entomopathogenic nematodes in Rwanda. Egypt. J. Biol. Pest Co. 28, 2. https://doi.org/10.1186/s41938-017-0003-2

19. Kalleshwaraswamy C.M., Murthy S., Viraktamath C.A., Krishna N.K. (2015). Occurrence of Tuta absoluta (Lepidoptera: Gelechiidae) in the Malnad and Hyderabad-Karnataka regions of Karnataka, India. Fla Entomol, 98, 970-971. https://doi.org/10.1653/024.098.0326.

20. Kamali S., Karimi J., Koppenhofer A.M. (2018). New insight into the management of the tomato Leaf Miner, Tuta absoluta (Lepidoptera: Gelechiidae) with entomopathogenic nematodes. J. Econ. Entomol, 111, 112-119. https://doi.org/10.1093/jee/tox332.

21. Kaya H.K., Gaugler R. (1993) Entomopathogenic nematodes. Annual Review of Entomology, 38: 181206.https://doi.org/10.1146/annurev.en.38.010193.001145

22. Kaya H.K., (1990). Soil ecology, pp. 93-115. In R. Gaugler (eds.), Entomopathogenic nematodes in biological control. CRC Press, Boca Raton, FL.

23. Koppenhofer A.M., Fuzy E.M. (2006). Effect of soil type on infectivity and persistence of the entomopathogenic nematodes Steinernema scarabaei, Steinernema glaseri, Heterorhabditis zealandica, and Heterorhabditis bacteriophora. J. Invertebr. Pathol, 92, 11-22. https://doi.org/10.1016/j.jip.2006.02.003.

24. Kumari D.A., Anitha G., Anitha V., Lakshmi B.K.M., Vennila S., Rao N.H.P. (2015). New record of leaf miner, Tuta absoluta (Meyrick) in Tomato. Insect Environ, 20, 136-138.

25. Lacey L.A., Grzywacz D., Shapiro-llan D.I., Frutos R., Brownbridge M., Goettel M.S. (2015). Insect pathogens as biological control agents: back to the future. J. Invertebr. Pathol, 132, 1-41. https://doi.org/10.1016/j.jip.2015.07.009.

26. Lacey L.A., Grzywacz D., Shapiro-llan D.I., Frutos R., Brownbridge M., Goettel M.S. (2015). Insect pathogens as biological control agents: back to the future. J. Invertebr. Pathol, 132, 1-41. https://doi.org/10.1016/j.jip.2015.07.009.

27. Lewis E.E., Campbell J.C., Griffn C., Kaya H.K., Peters A. (2006). Behavioural ecology of entomopathogenic nematodes. Biolog Control, $38,66-79$. https://doi.org/10.1016/j.biocontrol.2005.11.007.

28. Liu J.F., Yang M.F., Hu J.F., Han C. (2015). Effects of temperature on development and survival of Orthopygia glaucinalis (Lepidoptera: Pyralidae) reared on Platycarya stobilacea. J Econ Entomol, 108, 504-514. https://doi.org/10.1093/jee/tov003.

29. Mahmoud M.F. (2016). Biology and use of entomopathogenic nematodes in insect pests biocontrol, a generic view. Cerc. Agron. Mold, $49,85-105$. https://doi.org/10.1515/cerce-2016-0039. 
30. Ndereyimana A., Nyalala S., Murerwa P., Gaidashova S. (2019a). Bioactivity of plant extracts against tomato leaf miner, Tuta absoluta (Meyrick) (Lepidoptera: Gelechiidae). J. Appl. Hortic, 21, 146-150.

31. Ndereyimana A., Nyalala S., Murerwa P., Gaidashova S. (2019b). Pathogenicity of some commercial formulations of entomopathogenic fungi on the tomato leaf miner, Tuta absoluta (Meyrick) (Lepidoptera: Gelechiidae). Egypt. J. Biol. Pest Co, 29, 70. https://doi.org/10.1186/s41938-019-0184-y.

32. Ndereyimana A., Nyalala S., Murerwa P., Gaidashova S. (2019c). Potential of entomopathogenic nematode isolates from Rwanda to control the tomato leaf miner, Tuta absoluta (Meyrick) (Lepidoptera: Gelechiidae). Egypt. J. Biol. Pest Co, 29 (1), 57. https://doi.org/10.1186/s41938-019-0163-3.

33. Nilahyane A., Bouharroud R., Hormatallah A., Taadaouit N.A. (2012). Larvicidal effect of plant extracts on Tuta absoluta (Lepidoptera: Gelechiidae). IOBC/WPRS Bull, 80, 305-310.

34. Portman S., Sindhu M., Reddy G.V.P. (2016). Entomopathogenic nematodes combined with adjuvants presents a new potential biological control method for managing the wheat stem sawfly, Cephus cinctus (Hymenoptera: Cephidae). PLoS One, doi: 10.1371/journal.pone.0169022.

35. Rezaei N., Karimi J.M., Hosseini M., Goldani., Campos-Herrera R. (2015). Pathogenicity of two species of entomopathogenic nematodes against the greenhouse whitefly, Trialeurodes vaporariorum (Hemiptera: Aleyrodidae), in laboratory and greenhouse experiments. J. Nematol, 47, 60-66.

36. Roditakis E., Skarmoutsou C., Staurakaki M. (2013). Toxicity of insecticides to populations of tomato borer Tuta absoluta (Meyrick) from Greece. Pest Manage Sci, 69, 834-840. https://doi.org/10.1002/ps.3442.

37. Roditakis E., Vasakis E.A., Grispou M., Stavrakaki M., Nauen R., Gravouil M., Bassi A. (2015). First report of Tuta absoluta resistence to diamide insecticides. J Pest Sci, 88, 9-16. https://doi.org/10.1007/s10340-015-0643-5

38. Shamseldean M.S.M., Abd-Elbary N.A., Shalaby H., Ibraheem H.I.H. (2014). Entomopathogenic nematodes as biocontrol agents of the tomato leaf miner Tuta absoluta (Meyrick) (Lepidoptera: Gelechiidae) on tomato plants. Egyptian Journal of Biological Pest Control, 24, 503-513.

39. Shams-El-Din M.M., Abdel-Bari N.A., Shalaby H., Ibrahim H.E. (2014). Entomopathogenic nematodes as biocontrol agents of the tomato leaf miner Tuta absoluta (Meyrick) (Lepidoptera: Gelechiidae) on tomato plants. Egypt. J. Biol. Pest Co, 24 (2).

40. Sharma P.L., Gavkare O. (2017). new distributional record of invasive pest Tuta absoluta (Meyrick) in North-Western Himalayan region of India. Nat Acad Sci Lett, 40, 217-220. https://doi.org/10.1007/s40009-016-0526-1.

41. Shashank P.R., Chandrashekar K., Naresh M.M., Sreedevi K. (2015). Occurrence of Tuta absoluta (lepidoptera: gelechiidae) an invasive pest from India. Indian J Ent. 77, 323-329. https://doi.org/10.5958/0974- 8172.2015.00070.X.

42. Sicard M., Brugirard-Ricaud K., Pages S., Lanois A., Boemare N.E., Brehelin M., Givaudan, A. (2004). Stages of infection during the tripartite interaction between Xenorhabdus nematophila, its nematode vector, and insect hosts. Appli and Environ Microb, 70, 6473-6480. https://doi.org10.1128/AEM.70.11.6473-6480.2004.

43. Sreedevi G., Prasad Y.G., Prabhakar M., Rao G.R., Vennila S., Venkatswarlu B. (2013). Bioclimatic thresholds, thermal constants and survival of mealybug, Phenacoccus solenopsis (Hemiptera: Pseudococcidae) in response to constant temperature on hibiscus. PLoS One 8, e75636. https://doi.org/10.1371/journal.pone.0075636.

44. Sridhar V., Chakravarthy A.K., Asokan R., Vinesh L.S., Rebijith K.B., Vennila S. (2014). New record of the invasive South American tomato leaf miner, Tuta absoluta (Meyrick) (Lepidoptera: Gelechiidae) in India. Pest Manage Hort Ecosys, 20, 148-154

45. Tadele S., Emana G. (2017). Entomopathogenic effect of Beauveria bassiana (Bals.) and Metarhizium anisopliae (Metschn.) on Tuta absoluta (Meyrick) (Lepidoptera: Gelechiidae) larvae under laboratory and glasshouse conditions in Ethiopia. J. Plant Pathol. Microbiol, 8, 2. https://doi.org/10.4172/21577471.1000411.

46. Urbaneja A., Gonzalez-Cabrera J., Arno J., Gabarra R. (2012). Prospects for the biological control of Tuta absoluta in tomatoes of the Mediterranean basin. Pest Manage Sci, 68, 1215-1222. https://doi.org/10.1002/ps.3344.

47. Urbaneja A.R., Vercher V., Navarro F., Mari G., Porcuna J.L. (2008). La polilla del tomato, Tuta absoluta. Phytoma Espana, $194,16-23$. http://hdl.handle.net/20.500.11939/4087.

48. Van Damme V.M., Beck B.K., Berckmoes E., Moerkens R., Wittemans L., De Vis R. (2016). Efficacy of entomopathogenic nematodes against larvae of Tuta absoluta in the laboratory. Pest Manag. Sci, 72, 1702-1709. https://doi.org/10.1002/ps.4195.

49. Yan X., Waweru B., Qiu X., Hategekimana A., Kajuga J., Li H. (2016). New entomopathogenic nematodes from semi-natural and small-holder farming habitats of Rwanda. Biocontrol Sci. Technol, 26, 820-834. https://doi.org/10.1080/09583157.2016.1159658.

50. Zhang G., Zong L., Duan H., Xiong J., Lu R., Lu F. (2008). Spatial distribution of the flower bug, Orius similis and its interaction with the pink bollworm, Pectinophora gossypiella in cotton fields. Int J Pest Manage, 40, 309-312. https://doi.org/10.1080/09670879409371905

\section{Figures}

Figures 1-4 are not available with this version. 